\title{
Cryptococcal antigenemia and its predictors among HIV infected patients in resource limited settings: a systematic review
}

Awoke Derbie ( $\sim$ awe.love2000@gmail.com )

Bahir Dar University

Daniel Mekonnen

Bahir Dar University

Yimtubezinash Woldeamanuel

Addis Ababa University School of Medicine

Tamrat Abebe

Addis Ababa University School of Medicine

Research article

Keywords: Cryptococcal antigenemia, Predictors, Resource limited settings

Posted Date: March 12th, 2020

DOI: https://doi.org/10.21203/rs.2.15642/v2

License: (c) (i) This work is licensed under a Creative Commons Attribution 4.0 International License. Read Full License

Version of Record: A version of this preprint was published at BMC Infectious Diseases on June 11th, 2020. See the published version at https://doi.org/10.1186/s12879-020-05129-w. 


\section{Abstract}

Background: Cryptococcosis is an opportunistic fungal infection that primarily affects people with advanced HIV/AIDS and is an important cause of morbidity and mortality around the globe. By far the most common presentation of the disease is cryptococcal meningitis (CM), which leads to an estimated $15-20 \%$ of all HIV related deaths worldwide, $75 \%$ of which are in sub-Saharan Africa. However, to the best of our knowledge there is quite limited reviewed data that on the epidemiology of cryptococcal antigenemia in a large HIV-infected population in resource limited settings. Methods: Articles published in English irrespective of the time of publication were systematically searched using comprehensive search strings from PubMed/Medline and SCOPUS. In addition, Google Scholar and Google databases were searched manually for grey literature. Two reviewers independently assessed study eligibility, extracted data, and assessed risk of bias. The magnitude of cryptococcal antigenemia and its predictors were presented with descriptive statistics and summary measures. The pooled prevalence of cryptococcal antigenemia was also determined with 95\% confidence interval (CI). Result: Among 2941 potential citations, we have included 22 studies with a total of 8,338 HIV positive individuals. The studies were reported in ten different countries during the year (2007-2018). Most of the articles reported the mean CD4 count of the participants $<100$ cells $/ \mu$ l. The pooled prevalence of cryptococcal antigenemia at different CD4 count and ART status was at $8 \%$ (95\% Cl: $6-10 \%$ ) (ranged between $1.7 \%$ and $33 \%$ ). Body mass index $(\mathrm{BMI})<18.5 \mathrm{~kg} / \mathrm{m} 2, \mathrm{CD} 4$ count $<100$ cells, presenting with headache and male gender were reported by two or more articles as an important predictors of cryptococcal antigenemia. Conclusions: Implementing a targeted screening of HIV patients with low BMI, CD4 count $<100$ cells, having headache and males; and treatment for asymptomatic cryptococcal disease should be considered. Additional data is needed to better define the epidemiology of cryptococcal antigenemia and its predictors in resource limited settings in order to design prevention, diagnosis, and treatment strategies.

\section{Background}

According to the 2019 United Nations Programme on AIDS (UNAIDS) report, around 37.9 million people globally were living with HIV in 2018. In the same year, about 1.7 million people were newly infected and 700, 000 people died from AIDS-related illnesses globally [1]. Cryptococcosis is one of the most important opportunistic infections among people living with advanced AIDS having defective cellular immune component and is a major contributor to AIDS-related mortality worldwide [2]. In spite of the increasing availability of antiretroviral treatment (ART), cryptococcal disease continues to be a leading cause of death among HIV infected patients in the developing world [3-5]. Considerable number of HIV-infected population still presents late to care with advanced AIDS [6-7].

The burden of the disease is greatest in middle and low-income countries where there is a high prevalence HIV infection [8-13]. Patients taking immunosuppressive drugs and some immunocompetent hosts are also at risk [14]. Although the infection begins in the lungs, certainly the most common presentation of cryptococcal disease, representing $70-90 \%$ of HIV-related cryptococcal disease, is cryptococcal meningitis (CM), which accounts for $15 \%-20 \%$ of all AIDS-related deaths globally, three 
quarters of which are in sub-Saharan Africa. Coupled with loose adherence to ART and retention in HIV care an estimated 223, 100 cases of CM resulted in 181, 100 deaths among people living with HIV in $2014[2,4,7,13,15]$. Screening patients for subclinical cryptococcal infection at the time of entry into ART programs using point-of-care tools like, cryptococcal antigen ( $\mathrm{CrAg}$ ) immunoassays is highly effective in identifying patients at risk of developing $\mathrm{CM}$, allowing these patients to then be targeted with pre-emptive antifungal therapy to prevent the development of severe disease and mortality [16].

Cryptococcal infection is primarily caused by Cryptococcus neoformans and $C$. gattii species $[8,9]$. $C$. neoformans is an encapsulated yeast that can be found in pigeon droppings which causes mild to severe infections like meningitis or disseminated disease in individuals with impaired immunity [10]. The yeast demonstrates several well-characterized virulence factors that contribute to the success of infection. To mention the common one; tolerance to mammalian body temperature at $37^{\circ} \mathrm{C}$, owning a polysaccharide capsule that protects the yeast from phagocytosis, and a thick cell wall with the deposition of phenolic melanin, which has been proposed to protect the yeast from oxidation $[11,12]$.

While the gold standard for diagnosis of cryptococcal disease is culture from bodily fluids, CrAg test is used to presumptively diagnose the disease with sensitivity and specificity close to $100 \%$. There are several methods to detect cryptococcal antigen in CSF or plasma/serum: latex agglutination (LA), enzyme immunoassay (EIA), and lateral flow assay (LFA)[6]. Recent advances in point-of-care testing, like CrAg test, has made screening and diagnosis of CM rapid, practical, and affordable and have been improving long-term survival. Targeted screening and pre-emptive treatment programs for CrAg are a cost effective method for reducing early mortality [17].

Some of the independent predictors of positive serum cryptococcal antigenemia includes; CD4(+) T cell counts of $\leq 100$ cells $/ \mathrm{mm}$, low body mass index, presenting with neck pain, signs of meningeal irritation, and a recent diagnosis of HIV infection [18-21]. Routine screening of such category of patients may detect cryptococcosis, and hence provide an opportunity for early intervention.

Despite the high burden of cryptococcal meningitis related morbidity and mortality in resource limited settings, reviewed data on magnitude of cryptococcal antigenemia and its predictors is missing [22, 23]. Hence, data is required on this field to inform policy makers for input to tailor intervention measures. Therefore, this systematic review was conducted to describe the the level of cryptococcal antigenemia and its predictors in resource limited settings.

\section{Methods}

\section{Protocol registration}

In accordance with the PRISMA guidelines, this systematic review protocol was registered by the International Prospective Register of Systematic Reviews (PROSPERO) on 01 Feb 2019 with a registration number 'CRD42019119970'. 


\section{Eligibly criteria}

Studies were selected according to the following criteria; Study design: observational quantitative studies, like cross-sectional and cohort studies that reported the magnitude of cryptococcal antigenemia and its predictors. Participants: We included studies that employed HIV infected people irrespective of gender and the age group who were tested for cryptococcal antigenemia. Interventions: our interests were 1) the level of cryptococcal antigenemia, which was defined as the presence of cryptococcal $\mathrm{Ag}(\mathrm{CrAg})$ in the blood (serum or plasma) and 2) its predictors, which are to mean factors that are statistically associated with the positive cryptococcal Ag test in the blood. Setting. we included studies with the outcome of interest reported in resource-limited settings (countries, listed as low and middle income economic status based on the 2018/19 World Bank report) [24]. Language and publication: We considered peer-reviewed journal articles, governmental documents and unpublished articles (thesis) reported in English language irrespective of the year of publication.

\section{Information sources and search strategy}

This review was done following the Preferred Reporting Items for Systematic Reviews and Meta-Analysis Protocols (PRISMA) Guidelines [25]. Research papers were systematically searched in PubMed/Medline and SCOPUS, the last search was conducted on $22^{\text {th }}$ of Dec, 2018. Manual search from Google scholar and Google databases was also done for grey literature. The search terms were developed in line with the Medical Subject Headings (MeSH) thesaurus using a combination of the big ideas (or 'key terms') which derived from the research question. The reference lists of retrieved articles were probed (forward and back ward searching) to identify articles that were not retrieved from databases and our manual search. The first two authors; $A D$ and $D M$ searched the articles independently.

The domains of the search terms were Cryptococcus, cryptococcal antigenemia, cryptococcal meningitis, cryptococcosis, cryptococcal antigen/CrAg, associated factors/risk factors (or predictors), HIV, AIDS and resource-limited setting/countries. We combined cryptococcal antigenemia, cryptococcal meningitis, cryptococcosis with the Boolean operator "OR", and the result was combined with the other terms with "AND". Full search strategy for the two databases is presented in Supplement 1.

\section{Study selection}

Research papers that reported the level of cryptococcal antigenemia and its epidemiological predictors in the stated settings were included. Searched articles were directly imported and handled using EndNote X5 citation manager (Thomson Reuters, New York, USA). Based on the PRISMA protocol, duplicated articles were excluded and the titles and abstracts of the remaining papers were screened independently for inclusion in full text evaluation by the first two authors. Differences between the reviewers were resolved through discussion. In case of disagreements the decision was determined by the last author.

\section{Data collection process and data items}


Data such as the name of the first author, data collection period and year of publication, country where the study was conducted, mean/median age of the study participants, proportion of male participants, type of the study design, the total number of the study participants, the type of specimen (serum/plasma) used for the CrAg test, the proportion of cryptococcal Ag test result, reported statistically significant predictors for CrAg positive test were extracted from the included articles.

\section{Quality appraisal}

To assess the risk of bias, the two authors independently used the nine items (each score one point) based on the Joanna Briggs Institute (JBI) Critical Appraisal tools [26] for prevalence studies. We assumed that papers that scored $>50 \%$ (i.e $\geq 5$ of 9 scores) of the weighted value of the tool considered as good quality.

\section{Data synthesis}

The data extracted from the included studies were fed into a Microsoft Excel and were presented in terms of 1 ) the proportion of cryptococcal antigenemia from each study; 2) meta-analysis was done to determine the pooled prevalence of cryptococcal antigenemia. A systematic narrative synthesis was provided in which summary results were presented using text, table and figures. Descriptive statistics, such as: simple counts, ranges and percentages were used to describe the synthesized data.

\section{Results}

\section{Search results}

From the systematically searched databases and other sources, a total of 2941 articles were retrieved and sequentially screened. After removing the duplicate, 2930 were screened by title then 2865 were removed. Consequently, 36 were removed by abstract and 7 by full text with justifiable reasons. Lastly, a total of 22 studies met our inclusion criteria and included in this review for analysis.

Screening was based on the PRISMA flow chart which was adapted from the PRISMA guidelines [27] (Figure 1).

\section{Study characteristics}

The description of each study is presented in (Table 1). The studies were reported in the last decade (2007-2018) in ten different countries. Except three studies that reported in Brazil, Indonesia and Cambodia, [28-30] the rest were conducted in Africa. All the included articles were published in peerreviewed journals. About $19(86.4 \%)$ of the articles used cross-sectional study design; while the remaining three papers were cohort type. The primary interest of most the included papers were to determine the prevalence of cryptococcal antigenemia among HIV infected patients using rapid CrAg test kits. 
In this review, data of 8,338 HIV positive individuals (male gender $25 \%-76.3 \%$ and median age range 30 40 years) were included.

\section{Table 1: Characteristics of the included studies}

\begin{tabular}{|c|c|c|c|c|c|c|c|}
\hline Author (s) & $\begin{array}{l}\text { *Pub. } \\
\text { Year }\end{array}$ & Country & $\begin{array}{l}\text { Study } \\
\text { period }\end{array}$ & $\begin{array}{l}\text { Study } \\
\text { design }\end{array}$ & $\begin{array}{l}\text { Sample } \\
\text { size }\end{array}$ & $\begin{array}{l}\text { Gender, } \\
\text { male (\%) }\end{array}$ & $\begin{array}{l}\text { Median/ } \\
\text { Mean/ } \\
\text { age }\end{array}$ \\
\hline $\begin{array}{l}\text { Vidal et al. } \\
\text { [28] }\end{array}$ & 2016 & Brazil & 2014-15 & CS* & 163 & 61 & 38.3 \\
\hline Ganiem et al. & 2014 & Indonesia & 2014 & CS & 810 & 76.3 & 30 \\
\hline Cheryl et al. & 2007 & Uganda & 2003-7 & CS & 377 & 29.4 & 38 \\
\hline $\begin{array}{l}\text { Beyene et al. } \\
\text { [32] }\end{array}$ & 2013 & Ethiopia & 2011-12 & CS & 254 & 45.3 & 33 \\
\hline $\begin{array}{l}\text { Meya et al. } \\
\text { [33] }\end{array}$ & 2010 & Uganda & 2004-6 & CS & 609 & 31 & no data \\
\hline $\begin{array}{l}\text { Rugemalila et } \\
\text { al.[34] }\end{array}$ & 2013 & Tanzania & 2011-12 & CS & 218 & 43 & 39 \\
\hline $\begin{array}{l}\text { Longley et al. } \\
\text { [35] }\end{array}$ & 2016 & S. Africa & 2011-14 & Cohort & 645 & 47 & 36 \\
\hline $\begin{array}{l}\text { Hailu et al. } \\
\text { [36] }\end{array}$ & 2017 & Ethiopia & 2016-7 & CS & 267 & 49 & 38 \\
\hline $\begin{array}{l}\text { Letang et al. } \\
\text { [37] }\end{array}$ & 2015 & Tanzania & 2008-12 & Cohort & 750 & 40 & 38 \\
\hline $\begin{array}{l}\text { Christopher et } \\
\text { al.[38] }\end{array}$ & 2015 & Nigeria & 2010-11 & CS & 333 & 46.8 & 33 \\
\hline $\begin{array}{l}\text { Williams et al. } \\
\text { [39] }\end{array}$ & 2015 & Uganda & 2013-14 & CS & 207 & 60.3 & 36 \\
\hline $\begin{array}{l}\text { Alemu et al. } \\
\text { [40] }\end{array}$ & 2013 & Ethiopia & 2011 & CS & 369 & 44 & 36 \\
\hline $\begin{array}{l}\text { Derbie et al. } \\
\text { [41] }\end{array}$ & 2018 & Ethiopia & 2016 & CS & 137 & 45.3 & 32 \\
\hline $\begin{array}{l}\text { Mamuye et al. } \\
\text { [42] }\end{array}$ & 2016 & Ethiopia & 2013-14 & CS & 198 & 53 & 36.7 \\
\hline $\begin{array}{l}\text { Oyella et al. } \\
\text { [43] }\end{array}$ & 2012 & Uganda & 2009-10 & CS & 367 & 48 & 32 \\
\hline $\begin{array}{l}\text { Ogouyemi et } \\
\text { al.[18] }\end{array}$ & 2016 & Benin & 2015 & CS & 355 & 42.3 & 40 \\
\hline $\begin{array}{l}\text { Drain et al. } \\
{[44]}\end{array}$ & 2015 & S. Africa & 2011-13 & CS & 432 & 60 & 36.1 \\
\hline $\begin{array}{l}\text { Mdodo et al. } \\
\text { [45] }\end{array}$ & 2010 & Kenya & 2008-9 & CS & 340 & 47.5 & 35 \\
\hline $\begin{array}{l}\text { Micol et al. } \\
{[30]}\end{array}$ & 2007 & Cambodia & 2004 & CS & 327 & 55 & 35 \\
\hline $\begin{array}{l}\text { Jarvis et al. } \\
{[46]}\end{array}$ & 2009 & $\begin{array}{l}\text { South } \\
\text { Africa }\end{array}$ & $2002-5$ & CS & 707 & 25 & 33.5 \\
\hline $\begin{array}{l}\text { Wajanga et al. } \\
\text { [47] }\end{array}$ & 2011 & Tanzania & 2009-10 & Cohort & 333 & 46.2 & 38.5 \\
\hline $\begin{array}{l}\text { Magambo et } \\
\text { al. [48] }\end{array}$ & 2014 & Tanzania & 2012-13 & CS & 140 & 42.1 & 36 \\
\hline
\end{tabular}


${ }^{*}$ CS: Cross-sectional study design.

\section{Risk of bias}

The nine domain-based JBI Critical appraisal tool [26] for prevalence studies was used to test outcome level risk of bias of each studies. Each domain had a score of 1 point. The risk of bias for each individual domain was measured as 'yes', 'no', 'unclear' and 'not applicable'. In this study, 'yes' scored 1 and 'no' 'unclear' and 'not applicable' scores zero. The score therefore ranges from zero to nine, with higher scores indicating higher quality of outcome. Based on our assumption the overall score ranged 5-7 (i.e all the included articles scored above $50 \%$ positive score). Hence, we considered all as good quality articles.

\section{Level of Cryptococcal antigenemia}

The reported median CD4 count was between 23 and 123cell/. Except a study [40] that reported mean CD 4 count at 123 cells/ $\mu$, the rest reported the mean CD4 count $<100$ cells. With regard to ART status of the participants, twelve studies $[18,29-31,33,35,37,43,44,46-48]$ included patients who were ART naïve. In contrast, two studies $[38,41]$ included participants who were on ART. The remaining articles reported different proportion of ART status of the participants. In addition, the reported proportion of headache (ranged between $10 \%$ and $80.6 \%$ ) and WHO clinical stage IV AIDS (ranged between $17.9 \%$ and $100 \%$ ) by the included articles is depicted in Table 2.

The overall reported prevalence of cryptococcal antigenemia was between $1.7 \%$ and $33 \%$. Running metaanalysis, the pooled prevalence was at $8 \%$ (95\%Cl: $6 \%-10 \%$ ) (Table 2 and Figure 2). Our sub-group analysis also showed that the prevalence of cryptococcal antigenemia in Ethiopia varied between $3.4 \%$ and $11.7 \%$. The pooled prevalence was at $7 \%(95 \% \mathrm{Cl}: 3-11 \%)$ among HIV infected patients at different ART status and CD4 count.

\section{Predictors of Cryptococcal antigenemia}

The statistically significant predictors of positive cryptococcal antigen test are depicted below in (Table 3 ). Body mass index $<18.5 \mathrm{~kg} / \mathrm{m} 2, \mathrm{CD} 4$ count $<100$ cells and male gender were reported by two or more articles as an important predictors of cryptococcal antigenemia.

Table 2: The proportion of cryptococcal antigemia and distribution of other clinical features of the study participants, 2007-2018 


\begin{tabular}{|c|c|c|c|c|c|}
\hline Author (s) & $\begin{array}{l}\text { Median CD4 } \\
\text { count }(\text { cells } / \mu \mathrm{l})\end{array}$ & $\begin{array}{l}\text { ART } \\
\text { status }\end{array}$ & $\begin{array}{l}\text { WHO stage } \\
I V(\%)\end{array}$ & $\begin{array}{l}\text { Had } \\
\text { headache } \\
(\%)\end{array}$ & $\begin{array}{c}+C r A g \text { test } \\
n(\%)\end{array}$ \\
\hline $\begin{array}{l}\text { Vidal et al. } \\
\text { [28] }\end{array}$ & 25 & $\begin{array}{l}74 \% \text { on } \\
\text { ART }\end{array}$ & 66 & No data & $5(3.1)$ \\
\hline $\begin{array}{l}\text { Ganiem et al. } \\
\text { [29] }\end{array}$ & 20 & All naïve & no data & No data & $58(7.1)$ \\
\hline $\begin{array}{l}\text { Cheryl et al. } \\
\text { [31] }\end{array}$ & 50 & All naïve & 36.2 & No data & $22(5.8)$ \\
\hline $\begin{array}{l}\text { Beyene et al. } \\
\text { [32] }\end{array}$ & -* & $\begin{array}{l}47.6 \% \text { on } \\
\text { ATR }\end{array}$ & 36.2 & 45.7 & $26(10.2)$ \\
\hline $\begin{array}{l}\text { Meya et al. } \\
\text { [33] }\end{array}$ & 79 & All naïve & No data & 45.7 & $50(8.2)$ \\
\hline $\begin{array}{l}\text { Rugemalila et } \\
\text { al.[34] }\end{array}$ & 96 & $\begin{array}{l}44 \% \text { on } \\
\text { ART }\end{array}$ & No data & 66 & $7(3)$ \\
\hline $\begin{array}{l}\text { Longley et al. } \\
\text { [35] }\end{array}$ & 55.5 & All naïve & No data & No data & $28(4.3)$ \\
\hline $\begin{array}{l}\text { Hailu et al. } \\
\text { [36] }\end{array}$ & $-* *$ & $\begin{array}{l}52 \% \text { on } \\
\text { ART }\end{array}$ & 45 & 33 & $9(3.4)$ \\
\hline $\begin{array}{l}\text { Letang et al. } \\
\text { [37] }\end{array}$ & 71 & All naïve & No data & No data & $28(3.7)$ \\
\hline $\begin{array}{l}\text { Christopher et } \\
\text { al.[38] }\end{array}$ & _*** & $\begin{array}{l}\text { All on } \\
\text { ART }\end{array}$ & No data & No data & 33 (9.9) \\
\hline $\begin{array}{l}\text { Williams et al. } \\
\text { [39] }\end{array}$ & 25 & $\begin{array}{l}51 \% \text { on } \\
\text { ART }\end{array}$ & No data & No data & $149(72)^{\wedge}$ \\
\hline $\begin{array}{l}\text { Alemu et al. } \\
\text { [40] }\end{array}$ & 123 & $\begin{array}{l}74 \% \text { on } \\
\text { ART }\end{array}$ & 100 & 28 & $31(8.4)$ \\
\hline $\begin{array}{l}\text { Derbie et al. } \\
\text { [41] }\end{array}$ & 51.8 & $\begin{array}{l}\text { All on } \\
\text { ART }\end{array}$ & No data & No data & $16(11.7)$ \\
\hline $\begin{array}{l}\text { Mamuye et al. } \\
\text { [42] }\end{array}$ & 93 & $\begin{array}{l}51 \% \text { on } \\
\text { ART }\end{array}$ & $36 \%$ & 39 & 18(9.1) \\
\hline $\begin{array}{l}\text { Oyella et al. } \\
\text { [43] }\end{array}$ & 23 & All naïve & No data & 37.1 & $69(19)$ \\
\hline $\begin{array}{l}\text { Ogouyemi et } \\
\text { al.[18] }\end{array}$ & -** & All naïve & No data & No data & $6(1.7)$ \\
\hline $\begin{array}{l}\text { Drain et al. } \\
\text { [44] }\end{array}$ & 75 & All naïve & No data & No data & $39(9)$ \\
\hline $\begin{array}{l}\text { Mdodo et al. } \\
\text { [45] }\end{array}$ & 72 & $\begin{array}{l}30.6 \% \text { on } \\
\text { ART }\end{array}$ & No data & 80.6 & $111(33)$ \\
\hline $\begin{array}{l}\text { Micol et al. } \\
\text { [30] }\end{array}$ & 24 & All naïve & $28 \%$ & 52.5 & 59 (18) \\
\hline $\begin{array}{l}\text { Jarvis et al. } \\
\text { [46] }\end{array}$ & 97 & All naïve & No data & No data & $46(7)$ \\
\hline $\begin{array}{l}\text { Wajanga et al. } \\
\text { [47] }\end{array}$ & 68 & All naïve & $17.9 \%$ & No data & $17(5.1)$ \\
\hline $\begin{array}{l}\text { Magambo et } \\
\text { al. [48] }\end{array}$ & 97 & All naïve & 66 & 10 & $10(7.1)$ \\
\hline
\end{tabular}

* Those who had CD4 <100 account at 59 (23.2\%); ** All CD4 counts were <100; *** those who had CD4<200 account at 121(36.3\%); ^ Outlier: subjects were HIV patients suspected for meningitis who were admitted to a hospital. The figure is excluded from the pooled prevalence analysis. 
Table 3: Reported factors associated with cryptococcal antigenemia among HIV infected patients in resource limited settings, 2007-2018.

\begin{tabular}{|c|c|}
\hline Author (S) & Reported predictors for positive CrAg test \\
\hline $\begin{array}{l}\text { Vidal et al. } \\
\text { [28] }\end{array}$ & No data \\
\hline $\begin{array}{l}\text { Ganiem et al. } \\
\text { [29] }\end{array}$ & No data \\
\hline Cheryl et al. & No data \\
\hline Beyene et al. & Being ART naive and ART-defaulter \\
\hline Meya et al. & A cryptococcal diagnosis during follow-up \\
\hline $\begin{array}{l}\text { Rugemalila } \\
\text { et al.[34] }\end{array}$ & No data \\
\hline $\begin{array}{l}\text { Longley et } \\
\text { al.[35] }\end{array}$ & No data \\
\hline Hailu et al. & Being male, living in rural areas, being hospitalized \\
\hline Letang et al. & No data \\
\hline $\begin{array}{l}\text { Christopher } \\
\text { et al.[38] }\end{array}$ & Female gender, CD4 count of $<200 \mathrm{cell} / \mu \mathrm{L}$ \\
\hline $\begin{array}{l}\text { Williams et } \\
\text { al.[39] }\end{array}$ & ( \\
\hline $\begin{array}{l}\text { Alemu et al. } \\
\text { [40] }\end{array}$ & $\begin{array}{l}\text { An increasing age, self-reported fever, CD } 4 \text { count }<100 \text { cells and site of } \\
\text { screening. }\end{array}$ \\
\hline $\begin{array}{l}\text { Derbie et al. } \\
\text { [41] }\end{array}$ & Gender \\
\hline $\begin{array}{l}\text { Mamuye et } \\
\text { al.[42] }\end{array}$ & $\begin{array}{l}\text { Lower median CD } 4 \text {, history of cryptococcal disease, having symptoms of } \\
\text { headache, head stiffness }\end{array}$ \\
\hline $\begin{array}{l}\text { Oyella et al. } \\
\text { [43] }\end{array}$ & $\begin{array}{l}\text { Low body mass index, CD } 4+\text { count of less than } 50 \text { cells } / \mathrm{mm} 3 \text {, recent } \\
\text { diagnosis of HIV infection and meningeal signs }\end{array}$ \\
\hline $\begin{array}{l}\text { Ogouyemi et } \\
\text { al.[18] }\end{array}$ & $\begin{array}{l}\text { Body mass index }<18.5 \mathrm{~kg} / \mathrm{m} 2 \text {, an alteration of the general condition with a } \\
\text { CD4 lymphocyte counts }<50 \text { cells } / \mu \mathrm{L}\end{array}$ \\
\hline $\begin{array}{l}\text { Drain et al. } \\
\text { [44] }\end{array}$ & CD 4 counts $<50$ cells $/ \mu \mathrm{L}$ \\
\hline $\begin{array}{l}\text { Mdodo et al. } \\
\text { [45] }\end{array}$ & male sex, headache, blurred vision and previous antifungal drug use \\
\hline $\begin{array}{l}\text { Micol et al. } \\
{[30]}\end{array}$ & $\begin{array}{l}\text { Countryside residence, headache, body mass index }<15.4 \mathrm{~kg} / \mathrm{m} 2 \text {, CD } 4+ \\
\text { count }<50 \text { cells } / \mathrm{mm} 3 \text {, male gender }\end{array}$ \\
\hline $\begin{array}{l}\text { Jarvis et al. } \\
\text { [46] }\end{array}$ & $\begin{array}{l}\text { Baseline CD } 4 \text { cell count, incident cryptococcal meningitis, history of } \\
\text { cryptococcal disease }\end{array}$ \\
\hline $\begin{array}{l}\text { Wajanga et } \\
\text { al.[47] }\end{array}$ & CD 4 counts of $<100$ cells, altered mental status, neck stiffness, fever \\
\hline $\begin{array}{l}\text { Magambo et } \\
\text { al. [48] }\end{array}$ & Age, body mass index, CD4 count and WHO stage \\
\hline
\end{tabular}


Cryptococcal meningitis, a deadly opportunistic fungal infection, is a leading cause of death among people with advanced HIV in resource limited settings $[15,49,50]$. However, it is one of the neglected topics by public health authorities while most deaths from the diseases are avoidable [23,50-53]. There is quite few data regarding the prevalence of cryptococcosis in resource limited settings for public health measure. Therefore, in this systematic review data of some 8,338 HIV positive individuals is described to uncover the magnitude of cryptococcal antigenemia and its possible predictors. The median age of the patients in the included studies range 30-40 years which implies that HIV infection continue affecting the productive segment of the population.

In this review the reported median CD 4 count of the HIV patients was between 23 and $123 \mathrm{cell} / \mu \mathrm{\mu}$. Except a study[40], the rest articles reported mean CD 4 count of the participants below 100 cells (range 23-97 cells $/ \mu$ l). On top of this twelve studies $[18,29-31,33,35,37,43,44,46-48]$ reported that all the participants were ART naïve. Consequently, low CD4 count coupled with not starting ART would expose HIV infected patients for higher risk of different opportunistic infections including, cryptococcosis.

Our review result showed the overall prevalence of cryptococcal antigenemia between $1.7 \%$ and $33 \%$; the pooled prevalence was at $8 \%(95 \% \mathrm{Cl}: 6-10 \%)$. A review by Firacative et al. (2018) on the status of cryptococcosis in Latin America reported prevalence of 10\%-21\% [22] in the context of HIV patients with $\mathrm{CM}$. Although the papers included in the present review recruited patients with different clinical ground, including their different CM status, our finding is still in line with the above report. Similarly, based on Rajasingham et al. (2017) review report on the Global burden of HIV-associated cryptococcal meningitis, the estimated global cryptococcal antigenaemia prevalence was at $6 \%(95 \% \mathrm{Cl} 5.8-6.2 \%)$ among people with a CD 4 cell count of less than 100 cells per $\mu \mathrm{L}$ in 2014 . This finding is in line with our pooled estimate at (8\%). In addition, according to this report the Sub-Saharan Africa accounted for $73 \%$ of the estimated cryptococcal meningitis cases in 2014. Moreover, the report also highlighted that there might be an ongoing burden of HIV-associated cryptococcal disease, primarily in sub-Saharan Africa[54].

Another review by Park et al. (2009) aimed at estimating the current global burden of cryptococcal meningitis among persons living with HIV showed an incidence ranged from 0.04 to $12 \%$ per year. SubSaharan Africa had the highest yearly burden estimate (median incidence at $3.2 \%$ ). In contrast, the median incidence was lowest in Western and Central Europe and Oceania $(</=0.1 \%$ each)[5]. This implies that the reported incidence joined with the existing cryptococcal cases, the overall prevalence of the disease would be much higher, may be close to or greater than our pooled report at (8\%), in poor settings. In contrast, the prevalence of cryptococcosis in the developed world has decreased as there is quite low burden of HIV and is also being diagnosed earlier, but is still significant, and the problem in resourcelimited settings is exceedingly high [55] in which over half of patients die within 10 weeks of diagnosis compared to as few as $10 \%$ of patients from developed nations [56].

The pooled prevalence of cryptococcal antigenemia in Ethiopia was at 7\% (95\% Cl: 3-11\%) among HIV infected patients at different clinical context. Comparable reports have been released in Ethiopia and overseas; Bite et al. (2016) had reported (8.5\%) positive cryptococcal antigenemia proportion in Addis 
Ababa, Ethiopia [57]. Thomsen et al. (2018) reported that, of HIV patients included in a study in GuineaBissau, (10\%) had a positive cryptococcal antigen test [58]. On top of this, in our review the pooled prevalence of cryptococcal antigenemia was $11 \%$ (Uganda), $4 \%$ (Tanzania) and $7 \%$ (South Africa). As the HIV patients had different CD4 count, ART status and other background variables, i.e due to clinical variability, minor variation in the prevalence of cryptococcal antigenemia is likely to happen in different settings. Further, as most of the participants had CD4 count less than 100 cells/ $\mu$, relatively higher proportion of Cryptococcal antigenemia is more likely to be reported among these immunosuppressed HIV patients in these settings [43]. In contrast to our result, a relatively lower prevalence $(2.9 \%)$ of Cryptococcal antigenemia among HIV/AIDS patients was reported in United States in 2012[21]. Difference in ART adherence and HIV care might contribute for the lower prevalence of the case in the US than most African countries.

With regard to the possible predictors of cryptococcal antigenemia, body mass index $<18.5 \mathrm{~kg} / \mathrm{m} 2, \mathrm{CD} 4$ count $<100$ cells, had headache and male gender were reported by two or more articles as an important predictors of cryptococcal antigenemia that could potentially be utilized for public health measures. These all might directly or indirectly contributed for reduced immune status of individuals that could put them at risk for different opportunistic infections, including cryptococcosis. Specifically, lower CD4 count has strong correlation with sever immune depletion, hence risk of opportunistic infections. Liechty et al. (2007) reported that among HIV-infected individuals with CD4 cell count $<100$ cells/ $\mu \mathrm{l}$, cryptococcal antigenemia was associated with a higher risk of death than CrAg negative participants [31]. Other studies in different settings also reported that lower CD 4 count (usually $<100$ cells $/ \mathrm{mm}$ ), low body mass index, having neck pain and signs of meningeal irritation were an important predictors of cryptococcal antigenemia [18-21]. Thomsen et al. (2018) reported that self-reported headache and fever were also predictors of a positive CrAg test [58].

In our review almost half of the papers reported $10 \%-80.6 \%$ proportion of headache and $17.9 \%$ and $100 \%$ proportion of clinical stage IV HIV disease among HIV patients. Few of other the included papers reported these variables as an important predictor cryptococcal antigenemia [30,45, 47, 48]. Therefore, concerned stakeholders and policy makers should consider target screening and management of HIV patients coming-up with such associated factors might decrease the morbidity and mortality associated with cryptococcal infection in resource limited settings.

\section{Strength and limitations}

To the best of our knowledge, this systematic review represents the first to present the magnitude of cryptococcal antigenemia and its predictors among HIV patients in resource limited settings. The other strong suit of this review is that it includes studies from different settings: Africa, Asia and Latin America that allowed incorporating a better representation of data for policy making.

However, our review should be interpreted in light of a couple of drawbacks including but not limited to the small number of included studies despite the setting covers large number of countries. Especially, Latin America is underrepresented in this review. As a result, the absence of data from some countries 
might compromise the overall picture of the magnitude of cryptococcal antigenemia and its predictors for clear understanding of the problem for further considerations. The review didn't provide data on the $\mathrm{CrAg}$ titer and specific cryptococcal species involved in positive CrAg tests. The other possible pitfall of this review is the variation in demographic characteristic of the study subjects (clinical variability). Finally, the other limit relates to the point in time analysis of studies with cross-sectional study designs, as majority of the articles were this type, which inherently could affect the overall picture of the magnitude of cryptococcal antigenemia. Restricting our inclusion criteria to include only articles published in English languages may have missed relevant studies and reduced the precision of our results.

\section{Conclusions}

The pooled prevalence of cryptococcal antigenemia among HIV infected patients at different CD 4 count and ART status was at $8 \%$. Body mass index $<18.5 \mathrm{~kg} / \mathrm{m}^{2}, \mathrm{CD} 4$ count $<100$ cells, presenting with headache and male gender were reported by two or more articles as an important predictors of cryptococcal antigenemia. Therefore, it will be good to consider routine screening for CrAg among HIV infected patients specifically those presenting with these predictors. Policy makers should consider the implementation of targeted screening and treatment interventions for asymptomatic cryptococcal antigenemia patients in resource limited settings. Meningitis associated with cryptococcosis might be a reflection of HIV treatment programme failure; therefore timely HIV testing and rapid linkage to care will have paramount importance for patients. Finally, further work is needed to better define the scope of the problem and track the epidemiology of this infection, in order to prioritize prevention, diagnosis, and treatment strategies.

\section{List Of Abbreviations}

AIDS

ART

C. neoformans

CD

$\mathrm{Cl}$

$\mathrm{CM}$

CNS

CrAg

CSF
Acquired Immunodeficiency Syndrome

Anti-Retroviral Therapy (or Treatment)

Cryptococcus neoformans

Cluster of Differentiation

Confidence Interval

Cryptococcal Meningitis

Central Nervous System

Cryptococcal Antigen

Cerebrospinal Fluid 


\section{Declarations}

Ethical Approval and Consent to participate: Not applicable in this section

Consent for publication: Not applicable in this section

Availability of data and material: All the generated data in this review are included in the manuscript.

Competing interests: Authors declare that they have no competing interests.

Funding: We have received no fund for this particular review.

Authors' contributions: AD and TA conceived the review topic and objectives. AD and DM participated in the study selection and data extraction. TM and YM reviewed the manuscript critically for its scientific content. All authors reviewed and approved the manuscript.

Acknowledgments: We would like to thank Bahir Dar and Addis Ababa Universities and CDT-Africa for the provided opportunity to undertake this review.

\section{References}

1. UNAIDS data 2019. [cited 4 March 2020]; Available from: https://www.unaids.org/sites/default/files/media_asset/2019-UNAIDS-data_en.pdf.

2. WHO. Guidelines for the diagnosis, prevention and management of cryptococcal disease in HIVinfected adults, adolescents and children: supplement to the 2016 consolidated guidelines on the use of antiretroviral drugs for treating and preventing HIV infection. 2018 [cited 201815 Dec]; Available from: http://apps.who.int/iris/bitstream/handle/10665/260399/9789241550277eng.pdf;jsessionid=3DD47D6B4F06AFA32280E2048900A316 ? sequence $=1$.

3. Meyer, A.C. and M. Jacobson, Asymptomatic cryptococcemia in resource-limited settings. Curr HIV/AIDS Rep, 2013. 10(3): p. 254-63.

4. Lawrence, D.S., T. Boyer-Chammard, and J.N. Jarvis. Emerging concepts in HIV-associated cryptococcal meningitis. Curr Opin Infect Dis, 2018. 30(10): p. 0000000000000514. 
5. Park BJ, Wannemuehler KA, Marston BJ, Govender N, Pappas PG, Chiller TM. Estimation of the current global burden of cryptococcal meningitis among persons living with HIV/AIDS. Aids, 2009. 23(4): p. 525-30.

6. Rajasingham, R., D.B. Meya, and D.R. Boulware, Integrating cryptococcal antigen screening and preemptive treatment into routine HIV care. J Acquir Immune Defic Syndr, 2012. 59(5).

7. Uptodate. Microbiology and epidemiology of Cryptococcus neoformans infection. $201817 \mathrm{Ju} 2018$ [cited 201815 Dec]; Available from: https://www.uptodate.com/contents/microbiology-andepidemiology-of-cryptococcus-neoformans-infection.

8. Kwon-Chung KJ, Fraser JA, Doering TL, Wang Z, Janbon G, Idnurm A et al. Cryptococcus neoformans and Cryptococcus gattii, the etiologic agents of cryptococcosis. Cold Spring Harb Perspect Med, 2014. 4(7).

9. Lortholary, O. Management of cryptococcal meningitis in AIDS: the need for specific studies in developing countries: Clin Infect Dis. 2007 Jul 1;45(1):81-3. doi: 10.1086/518583. Epub 2007 May 25.

10. Pescador Ruschel, M.A. and B. Thapa, Meningitis, Cryptococcal. Available from https://www.ncbi.nlm.nih.gov/books/NBK525986/. Accessed 15 June 2019.

11. Liu, T.B., D.S. Perlin, and C. Xue. Molecular mechanisms of cryptococcal meningitis. Virulence, 2012. 3(2): p. 173-81.

12. Hamilton, A.J. and J. Goodley. Virulence factors of Cryptococcus neoformans. Curr Top Med Mycol, 1996. 7(1): p. 19-42.

13. Jackson, A. and M.C. Hosseinipour. Management of cryptococcal meningitis in sub-saharan Africa. Curr HIV/AIDS Rep, 2010. 7(3): p. 134-42.

14. Sloan, D.J. and V. Parris. Cryptococcal meningitis: epidemiology and therapeutic options. Clin Epidemiol, 2014. 6: p. 169-82.

15. Loyse A, Thangaraj H, Easterbrook P, Ford N, Roy M, Chiller T et al. Cryptococcal meningitis: improving access to essential antifungal medicines in resource-poor countries. The Lancet Infectious Diseases, 2013. 13(7): p. 629-637.

16. Jarvis JN, Govender N, Chiller T, Park BJ, Longley N, Meintjes G et al. Cryptococcal Antigen Screening and Preemptive Therapy in Patients Initiating Antiretroviral Therapy in Resource-Limited Settings: A Proposed Algorithm for Clinical Implementation. Journal of the International Association of Physicians in AIDS Care, 2012. 11(6): p. 374-379.

17. Abassi, M., D.R. Boulware, and J. Rhein. Cryptococcal Meningitis: Diagnosis and Management Update. Curr Trop Med Rep, 2015. 2(2): p. 90-99.

18. Ogouyemi-Hounto A, Zannou DM, Ayihounton G, Ahouada C, Azon-Kouanou A, Acakpo J et al. Prevalence and factors associated with cryptococcal antigenemia in HIV-infected patients in Cotonou/Benin. J Mycol Med, 2016. 26(4): p. 391-397.

19. Oyella J, Meya D, Bajunirwe F, Kamya MR. Prevalence and factors associated with cryptococcal antigenemia among severely immunosuppressed HIV-infected adults in Uganda: a cross-sectional 
study. J Int AIDS Soc, 2012. 15(1): p. 1758-2652.

20. Magambo KA, Kalluvya SE, Kapoor SW, Seni J, Chofle AA, Fitzgerald DW et al. Utility of urine and serum lateral flow assays to determine the prevalence and predictors of cryptococcal antigenemia in HIV-positive outpatients beginning antiretroviral therapy in Mwanza, Tanzania. J Int AIDS Soc, 2014. 17(19040).

21. McKenney J, Bauman S, Neary B, Detels R, French A, Margolick J et al. Prevalence, correlates, and outcomes of cryptococcal antigen positivity among patients with AIDS, United States, 1986-2012. Clin Infect Dis, 2015. 60(6): p. 959-65.

22. Firacative C, Lizarazo J, Illnait-Zaragozí MT, Castañeda E. The status of cryptococcosis in Latin America. Memorias do Instituto Oswaldo Cruz, 2018. 113(7): p. e170554-e170554.

23. Bongomin F, Gago S, Oladele RO, Denning DW. Global and Multi-National Prevalence of Fungal Diseases-Estimate Precision. J Fungi, 2017. 3(4).

24. Group, T.W.B. World Bank Country and Lending Groups. 2018 [cited 201818 Dec]; Available from: https://datahelpdesk.worldbank.org/knowledgebase/articles/906519-world-bank-country-andlending-groups

25. Shamseer L, Moher D, Clarke M, Ghersi D, Liberati A, Petticrew M et al. Preferred reporting items for systematic review and meta-analysis protocols (PRISMA-P) 2015: elaboration and explanation. Bmj, 2015. 2(350).

26. Institute, T.J.B. The Joanna Briggs Institute Critical Appraisal tools for use in JBI Systematic Reviews: Checklist for Prevalence Studies. 2017 [cited 20181 Aug]; Available from: http://joannabriggs.org/research/critical-appraisal-tools.html.

27. Moher D, Liberati A, Tetzlaff J, Altman DG. Preferred reporting items for systematic reviews and meta-analyses: the PRISMA statement. PLoS Med, 2009. 6(7): p. 21.

28. Vidal JE, Toniolo C, Paulino A, Colombo A, Dos Anjos Martins M, da Silva Meira C et al. Asymptomatic cryptococcal antigen prevalence detected by lateral flow assay in hospitalised HIVinfected patients in Sao Paulo, Brazil. Trop Med Int Health, 2016. 21(12): p. 1539-1544.

29. Ganiem AR, Indrati AR, Wisaksana R, Meijerink H, van der Ven A, Alisjahbana B et al. Asymptomatic cryptococcal antigenemia is associated with mortality among HIV-positive patients in Indonesia. Journal of the International AIDS Society, 2014. 17(1): p. 18821.

30. Micol R, Lortholary O, Sar B, Laureillard D, Ngeth C, Dousset JP et al. Prevalence, determinants of positivity, and clinical utility of cryptococcal antigenemia in Cambodian HIV-infected patients. J Acquir Immune Defic Syndr, 2007. 45(5): p. 555-9.

31. Liechty CA, Solberg P, Were W, Ekwaru JP, Ransom RL, Weidle PJ et al. Asymptomatic serum cryptococcal antigenemia and early mortality during antiretroviral therapy in rural Uganda. Tropical Medicine \& International Health, 2007. 12(8): p. 929-935.

32. Beyene T, Woldeamanuel Y, Asrat D, Ayana G, Boulware DR. Comparison of Cryptococcal Antigenemia between Antiretroviral Naïve and Antiretroviral Experienced HIV Positive Patients at Two Hospitals in Ethiopia. PLoS One, 2013. 8(10): p. e75585. 
33. Meya DB, Manabe YC, Castelnuovo B, Cook BA, Elbireer AM, Kambugu A et al. Cost-Effectiveness of Serum Cryptococcal Antigen Screening to Prevent Deaths among HIV-Infected Persons with a CD4+ Cell Count $\leq 100$ Cells/ $\mu$ L Who Start HIV Therapy in Resource-Limited Settings. Clinical Infectious Diseases, 2010. 51(4): p. 448-455.

34. Rugemalila J, Maro VP, Kapanda G, Ndaro AJ, Jarvis JN. Cryptococcal antigen prevalence in HIVinfected Tanzanians: a cross-sectional study and evaluation of a point-of-care lateral flow assay. Trop Med Int Health, 2013. 18(9): p. 1075-1079.

35. Longley N, Jarvis JN, Meintjes G, Boulle A, Cross A, Kelly N et al. Cryptococcal Antigen Screening in Patients Initiating ART in South Africa: A Prospective Cohort Study. Clinical Infectious Diseases, 2016. 62(5): p. 581-587.

36. Hailu K, Niguse S, Hagos K, Abdulkader M. Cryptococcal antigenemia and associated risk factors among ART-naive and ART-experienced HIV-infected peoples at selected health institutions of Mekelle, Northern Ethiopia. Microbiologyopen, 2018. 2(10): p. 746.

37. Letang E, Müller MC, Ntamatungiro AJ, Kimera N, Faini D, Furrer $\mathrm{H}$ et al. Cryptococcal Antigenemia in Immunocompromised Human Immunodeficiency Virus Patients in Rural Tanzania: A Preventable Cause of Early Mortality. Open Forum Infectious Diseases, 2015. 2(2): p. ofv046-ofv046.

38. Christopher, A.E., O. Richard, and A.-I. Otibhor. Cryptococcus neoformans infection among human immunodeficiency virus patients on highly active antiretroviral therapy in Benin City, Nigeria. NZ J Med Lab Science, 2015. 69(1): p. 21-23.

39. Williams DA, Kiiza T, Kwizera R, Kiggundu R, Velamakanni S, Meya DB et al. Evaluation of Fingerstick Cryptococcal Antigen Lateral Flow Assay in HIV-Infected Persons: A Diagnostic Accuracy Study. Clinical Infectious Diseases, 2015. 61(3): p. 464-467.

40. Alemu AS, Kempker RR, Tenna A, Smitson C, Berhe N, Fekade D et al. High prevalence of Cryptococcal antigenemia among HIV-infected patients receiving antiretroviral therapy in Ethiopia. PLoS One, 2013. 8(3): p. 4.

41. Derbie A, Ayalew W, Mekonnen D, Alemu M, Mulugeta Y. Magnitude of Cryptococcal Antigenemia among HIV Infected Patients at a Referral Hospital, Northwest Ethiopia Ethiop J Health 2018. 28(4): p. 6.

42. Mamuye AT, Bornstein E, Temesgen O, Blumberg HM, Kempker RR. Point-of-Care Testing for Cryptococcal Disease Among Hospitalized Human Immunodeficiency Virus-Infected Adults in Ethiopia. Am J Trop Med Hyg, 2016. 95(4): p. 786-792.

43. Oyella J, Meya D, Bajunirwe F, Kamya MR. Prevalence and factors associated with cryptococcal antigenemia among severely immunosuppressed HIV-infected adults in Uganda: a cross-sectional study. Journal of the International AIDS Society, 2012. 15(1): p. 15.

44. Drain PK, Kleene JM, Coleman SM, Losina E, Katz JN, Giddy J et al. Prevalence of cryptococcal antigenuria at initial HIV diagnosis in KwaZulu-Natal. HIV Med, 2015. 16(10): p. 640-4.

45. Mdodo R, Brown K, Omonge E, Jaoko W, Baddley J, Pappas P et al. The prevalence, clinical features, risk factors and outcome associated with cryptococcal meningitis in HIV positive patients in Kenya. 
East Afr Med J, 2010. 87(12): p. 481-7.

46. Jarvis JN, Lawn SD, Vogt M, Bangani N, Wood R, Harrison TS. Screening for Cryptococcal Antigenemia in Patients Accessing an Antiretroviral Treatment Program in South Africa. Clinical Infectious Diseases, 2009. 48(7): p. 856-862.

47. Wajanga BM, Kalluvya S, Downs JA, Johnson WD, Fitzgerald DW, Peck RN. Universal screening of Tanzanian HIV-infected adult inpatients with the serum cryptococcal antigen to improve diagnosis and reduce mortality: an operational study. J Int AIDS Soc, 2011. 14(48): p. 1758-2652.

48. Magambo KA, Kalluvya SE, Kapoor SW, Seni J, Chofle AA, Fitzgerald DW et al. Utility of urine and serum lateral flow assays to determine the prevalence and predictors of cryptococcal antigenemia in HIV-positive outpatients beginning antiretroviral therapy in Mwanza, Tanzania. Journal of the International AIDS Society, 2014. 17(1): p. 19040.

49. Williamson PR, Jarvis JN, Panackal AA, Fisher MC, Molloy SF, Loyse A et al. Cryptococcal meningitis: epidemiology, immunology, diagnosis and therapy. Nat Rev Neurol, 2017. 13(1): p. 13-24.

50. Oladele RO, Bongomin F, Gago S, Denning DW. HIV-Associated Cryptococcal Disease in ResourceLimited Settings: A Case for "Prevention Is Better Than Cure"? J Fungi, 2017. 3(4).

51. Roy, M. and T. Chiller. Preventing deaths from cryptococcal meningitis: from bench to bedside. Expert Review of Anti-infective Therapy, 2011. 9(9): p. 715-717.

52. Antinori, S. New Insights into HIV/AIDS-Associated Cryptococcosis. Isrn Aids, 2013. 25(471363): p. 471363.

53. Molloy SF, Chiller T, Greene GS, Burry J, Govender NP, Kanyama C et al. Cryptococcal meningitis: $A$ neglected NTD? PLoS Neglected Tropical Diseases, 2017. 11(6): p. e0005575-e0005575.

54. Rajasingham R, Smith RM, Park BJ, Jarvis JN, Govender NP, Chiller TM et al. Global burden of disease of HIV-associated cryptococcal meningitis: an updated analysis. The Lancet Infectious Diseases, 2017. 17(8): p. 873-881.

55. Spec A, Powderly WG. Cryptococcal meningitis in AIDS. Handb Clin Neurol, 2018. 152: p. 139-150.

56. Tenforde MW, Wake R, Leeme T, Jarvis JN. HIV-Associated Cryptococcal Meningitis: Bridging the Gap Between Developed and Resource-Limited Settings. Curr Clin Microbiol Rep, 2016. 3: p. 92-102.

57. Adane B, Mulu H, Tigist G, Surafel F. Prevalence of Crytpococcal Infection in Patients Clinically Diagnosed to Have Meningitis in Ethiopia. Clinical Medicine Research, 2016. 5(4): p. 73-76.

58. Thomsen D, Hviid CJ, Honge BL, Medina C, Te DDS, Correira FG et al. Increased mortality among HIV infected patients with cryptococcal antigenemia in Guinea-Bissau. Pan Afr Med J, 2018. 29(18).

\section{Supplement 1}

\section{Supplement 1: Search Strategy}




\begin{tabular}{lr}
\hline PubMed & Scopus \\
\hline ((((("Meningitis, & ( TITLE-ABS-KEY ( meningitis ) OR TITLE-ABS-KEY ( \\
Cryptococcal"[Mesh])) OR & cryptococcal ) OR TITLE-ABS-KEY ( cryptococcosis ) \\
("Cryptococcosis"[Mesh] OR & OR TITLE-ABS-KEY ( "Cryptococcus gattii" ) OR \\
"Cryptococcus gattii"[Mesh] & TITLE-ABS-KEY ( "cryprococcus neoformans" ) AND \\
OR "Cryptococcus & TITLE-ABS-KEY ( "risk factor" ) AND TITLE-ABS-KEY ( \\
neoformans"[Mesh] )) AND & hiv ) OR TITLE-ABS-KEY ( "Acquired immnune \\
"Risk Factors"[Mesh]) AND & deficiency syndrome" ) AND TITLE-ABS-KEY ( \\
"HIV"[Mesh]) OR "Acquired & "developing countries" ) ) AND ( LIMIT-TO ( DOCTYPE , \\
Immunodeficiency Syndrome" & "ar" ) ) AND ( LIMIT-TO ( LANGUAGE, "English" ) ) \\
[Mesh]) AND "Developing & AND ( LIMIT-TO ( SRCTYPE , "j" ) ) \\
Countries"[Mesh] &
\end{tabular}

\section{Figures}

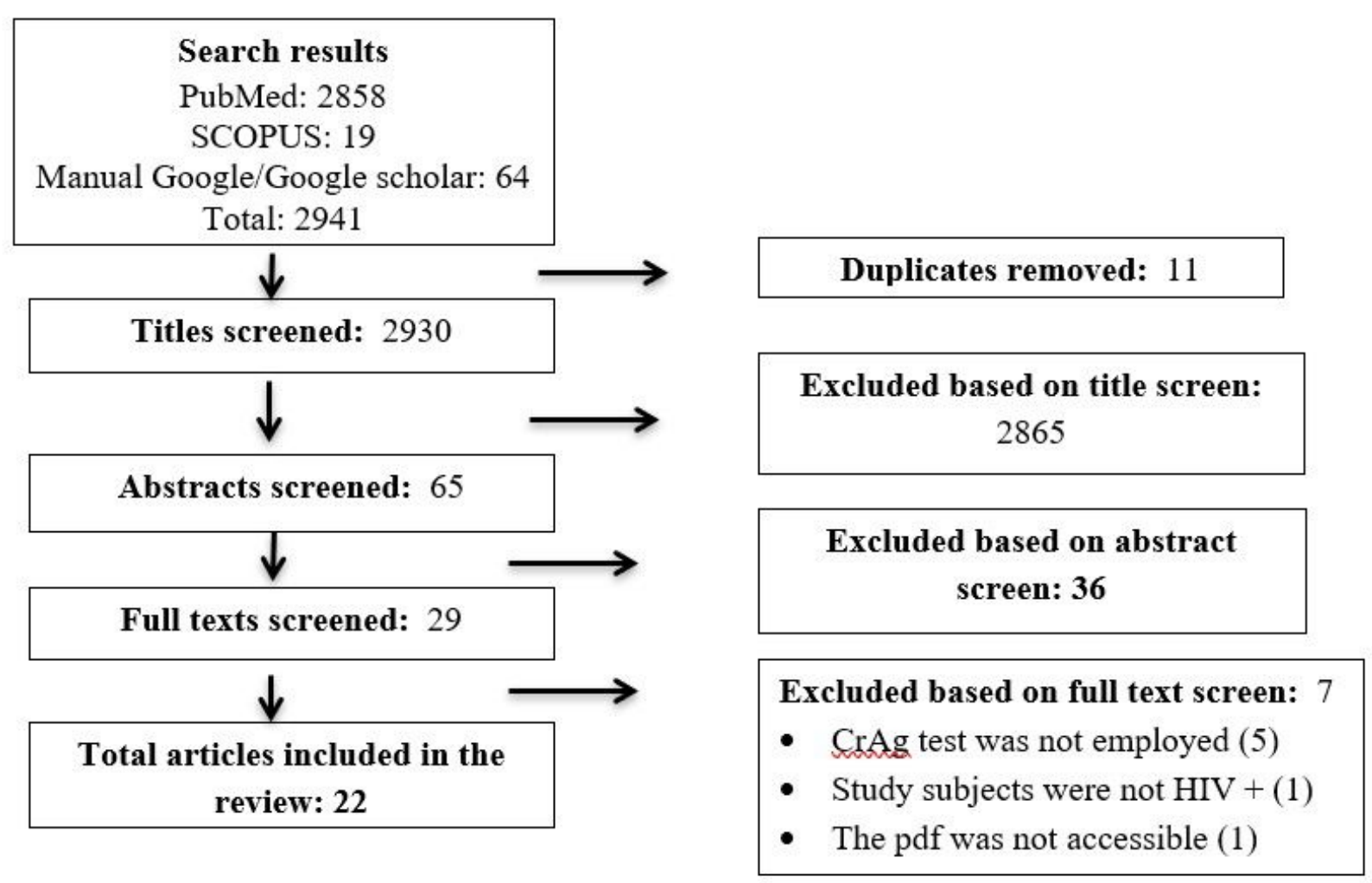

Figure 1

The PRISMA flow diagram of literature selection process. 


\begin{tabular}{|c|c|c|c|}
\hline \multicolumn{2}{|l|}{$\begin{array}{l}\text { Study } \\
\text { ID }\end{array}$} & \multirow{2}{*}{$\begin{array}{l}\text { ES }(95 \% \mathrm{Cl}) \\
0.03(0.00,0.06)\end{array}$} & \multirow{2}{*}{$\begin{array}{l}\% \\
\text { Weight } \\
4.87\end{array}$} \\
\hline Vidal et al. (2016) & $-\infty$ & & \\
\hline Ganiem et al. (2014) & + & $0.07(0.05,0.09)$ & 5.15 \\
\hline Cheryl et al. (2007) & -1 & $0.06(0.03,0.08)$ & 4.99 \\
\hline Beyene et al. (2013) & $\stackrel{1}{+\infty}$ & $0.10(0.06,0.14)$ & 4.53 \\
\hline Meya et al. (2010) & + & $0.08(0.06,0.10)$ & 5.05 \\
\hline Rugemalila et al. (2013) & -1 & $0.03(0.01,0.05)$ & 4.99 \\
\hline Longley et al. (2016) & +1 & $0.04(0.03,0.06)$ & 5.19 \\
\hline Hailu et al. (2017) & -1 & $0.03(0.01,0.06)$ & 5.05 \\
\hline Letang et al. (2015) & +1 & $0.04(0.02,0.05)$ & 5.23 \\
\hline Christopher et al. (2015) & 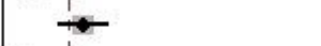 & $0.10(0.07,0.13)$ & 4.74 \\
\hline Alemu et al. (2013) & 1 & $0.01(-0.02,0.05)$ & 4.53 \\
\hline Derbie et al. (2018) & +1 & $0.12(0.06,0.17)$ & 3.91 \\
\hline Mamuye et al. (2016) & $\rightarrow-$ & $0.09(0.05,0.13)$ & 4.45 \\
\hline Oyella et al. (2012) & $: \rightarrow-$ & $0.19(0.15,0.23)$ & 4.45 \\
\hline Ogouyemi et al. (2016) & $\leftarrow$ & $0.02(0.00,0.03)$ & 5.23 \\
\hline Drain et al. (2015) & $\rightarrow$ & $0.09(0.06,0.12)$ & 4.87 \\
\hline Mdodo et al. (2010) & $\rightarrow$ & $0.33(0.28,0.38)$ & 3.98 \\
\hline Micol et al. (2007) & $\rightarrow-$ & $0.18(0.14,0.22)$ & 4.38 \\
\hline Jarvis et al. (2009) & + & $0.07(0.05,0.09)$ & 5.10 \\
\hline Wajanga et al. (2011) & $\rightarrow 1$ & $0.05(0.03,0.07)$ & 4.99 \\
\hline Magambo et al. (2014) & $\rightarrow$ & $0.07(0.03,0.11)$ & 4.30 \\
\hline Overall (I-squared $=93.0 \%, p=0.000)$ & $\diamond$ & $0.08(0.06,0.10)$ & 100.00 \\
\hline NOTE: Weights are from random effects analysis & & & \\
\hline & $\begin{array}{l}1 \\
1\end{array}$ & & \\
\hline
\end{tabular}

\section{Figure 2}

Frost plot for the pooled prevalence of cryptococcal antigenemia in resource limited settings. 